Case Reports in
Gastroenterology
Case Rep Gastroenterol 2020;14:453-457

DOI: 10.1159/000508930

Published online: September 15, 2020

(C) 2020 The Author(s)

Published by S. Karger AG, Base www.karger.com/crg

This article is licensed under the Creative Commons Attribution-NonCommercial 4.0 International License (CC BY-NC) (http://www.karger.com/Services/OpenAccessLicense). Usage and distribution for commercial purposes requires written permission.

\title{
Radiation Esophagitis in a Patient with Oral Carcinoma and Bone Metastasis
}

\author{
Toshimi Chiba $^{a} \quad$ Yu Ohashi ${ }^{b} \quad$ Naoko Tsunoda ${ }^{b} \quad$ Kei Onodera ${ }^{b}$ \\ Tadashi Kawai $^{\text {b }}$ Ikuya Miyamoto $^{\text {b }}$ Hiroyuki Yamada $^{\text {b }}$ \\ aDivision of Internal Medicine, Department of Oral Medicine, Iwate Medical University, \\ Morioka, Japan; ${ }^{b}$ Division of Oral and Maxillofacial Surgery, Department of Reconstructive \\ Oral and Maxillofacial Surgery, Iwate Medical University, Morioka, Japan
}

\section{Keywords}

Radiation esophagitis · Oral carcinoma · Bone metastasis

\begin{abstract}
Radiation esophagitis requiring endoscopic evaluation occurs quite rarely, affecting $<1 \%$ of patients undergoing radiation treatment. Acute radiation esophagitis develops within 3 weeks of radiation therapy. We describe herein a case of radiation esophagitis in a patient with oral carcinoma with multiple general bone metastases. Cisplatin, fluorouracil, and cetuximab were given for 3 cycles. Radiation therapy (30 Gy) to the thoracic vertebrae and lumbar vertebrae was prescribed to prevent worsening of bone metastases and relieve pain. Neutropenia was also observed due to chemotherapy. After the end of radiation therapy, the patient experienced chest pain, heartburn, and dysphagia. Upper gastrointestinal endoscopy revealed severe radiation esophagitis of endoscopic Fukui Acute Radiation Esophagitis grade 4. Oral food was discontinued and an intravenous proton-pump inhibitor was administered. After 3 weeks, upper gastrointestinal endoscopy showed improvement of radiation esophagitis, with scars. The symptoms of chest pain, heartburn, and dysphagia had also disappeared. This is the first case to be reported of acute radiation esophagitis in a patient with oral carcinoma with bone metastasis who experienced dramatic improvement of endoscopic findings. Neutropenia appears to be associated with more severe acute radiation esophagitis.
\end{abstract}




\section{Case Reports in Gastroenterology}

\begin{tabular}{l|l}
\hline Case Rep Gastroenterol 2020;14:453-457 \\
\hline DOI: 10.1159/000508930 & $\begin{array}{l}\text { @ 2020 The Author(s). Published by S. Karger AG, Basel } \\
\text { www.karger.com/crg }\end{array}$ \\
\hline
\end{tabular}

Chiba et al:: Radiation Esophagitis with Oral Carcinoma and Bone Metastasis

\section{Introduction}

Acute radiation esophagitis is an acute reaction that develops within 3 weeks of radiation therapy $[1,2]$. Patients develop dysphagia and odynophagia, which occur with radiation doses exceeding $30 \mathrm{~Gy}$ [3]. Acute onset of pain is related to early esophageal mucositis [4], and early onset of esophageal dysmotility may be due to radiation-induced damage of the Auerbach plexus $[2,5]$. The esophagus is one of the most radiosensitive mediastinal structures, and symptomatic radiation esophagitis is a rare complication of radiation treatment for breast, lung, and thoracic cancers [6]. The presence and grade of acute radiation esophagitis are assessed in accordance with the Common Terminology Criteria for Adverse Events (CTCAE v3.0) [7], while endoscopic findings are evaluated based on the Fukui Acute Radiation Esophagitis (FARE) classification criteria for acute radiation esophagitis [8].

Herein, we report a case with oral carcinoma with multiple bone metastases who developed acute radiation esophagitis, and describe the endoscopic findings 3 weeks after onset.

\section{Case Report}

A 60-year-old female was admitted to our hospital due to a diagnosis of oral carcinoma with multiple bone metastases to the thoracic vertebrae and lumbar vertebrae detected by positron emission tomography/computed tomography. 5-Fluorouracil and cisplatin chemotherapy $\left(1,000 \mathrm{mg} / \mathrm{m}^{2}\right.$ fluorouracil, $100 \mathrm{mg} / \mathrm{m}^{2}$ cisplatin $)+250 \mathrm{mg} / \mathrm{m}^{2}$ cetuximab was given for 3 cycles. Then, radiation therapy at 30 Gy (3 Gy/day) was administered to the thoracic vertebrae and lumbar vertebrae to prevent worsening of the bone metastases and to relieve pain.

The patient's blood neutrophil count decreased to $<500 / \mu \mathrm{L}$ due to chemotherapy, so the granulocyte colony-stimulating factor agent lenograstim was given. After radiation, she developed chest pain, heartburn, and dysphagia. Upper gastrointestinal endoscopy revealed erythema, ulceration, and spontaneous bleeding in the esophagus. Severe radiation esophagitis was diagnosed, determined to be endoscopic FARE grade 4 [9] (shown in Fig. 1) and CTCAE grade 3. Oral food was discontinued and an intravenous proton-pump inhibitor was administered.

After 3 weeks, upper gastrointestinal endoscopy showed a dramatic improvement of the radiation esophagitis to FARE grade 1 (shown in Fig. 2) and CTCAE grade 0 . The symptoms of chest pain, heartburn, and dysphagia had also disappeared. The blood neutrophil count was also recovered to $4,900 / \mu \mathrm{L}$.

\section{Discussion/Conclusion}

Symptomatic radiation esophagitis requiring endoscopic evaluation occurs quite rarely, affecting $<1 \%$ of patients receiving radiation treatment. Symptoms occur acutely, generally within the first 2 months [10]. Associations between radiation dose and clinically significant acute radiation esophagitis have been reported when the esophagus receives $\geq 35$ Gy $[9,11]$. In addition to esophageal dose-volume metrics, neutropenia may also be a risk factor for higher grades of acute radiation esophagitis [12]. Both concurrent chemoradiotherapy (CRT) and the volume that receives at least 35 Gy are predictors of acute esophageal toxicity [13]. In the present case, after 30 Gy of radiation therapy, the patient developed chest pain, heartburn, 


\section{Case Reports in Gastroenterology}

\begin{tabular}{l|l}
\hline Case Rep Gastroenterol 2020;14:453-457 \\
\hline DOI: 10.1159/000508930 & $\begin{array}{l}\text { ○ 2020 The Author(s). Published by S. Karger AG, Basel } \\
\text { www.karger.com/crg }\end{array}$ \\
\hline
\end{tabular}

Chiba et al.: Radiation Esophagitis with Oral Carcinoma and Bone Metastasis

and dysphagia, and neutropenia was observed. The CTCAE esophagitis grading scale is subjective, based on patient reporting of eating and swallowing symptoms that are scored from 0 to 4, and the FARE grade describes endoscopic findings of esophageal damage that are scored from 1 to 5 . A significant correlation between FARE grades and CTCAE esophagitis grades has been reported [8].

Histopathological findings of acute radiation esophagitis show apoptotic bodies in the basal zone, and fewer mitotic figures are noted within the first $48 \mathrm{~h} \mathrm{[6];} \mathrm{degeneration} \mathrm{of} \mathrm{mucosal}$ glands and a decreased number of acini or glands are also observed [4]. Submucosal endothelial swelling and capillary dilation are noticed within a few weeks [3]. Radiation esophagitis can be associated with complications, such as ulceration, perforation, and even tracheoesophageal fistula formation [2-4]; such complications are particularly likely to occur when adjuvant chemotherapy is administered [4]. The degree of radiation esophagitis was enhanced by chemotherapy [14]. The present case was treated with CRT, and severe radiation esophagitis was observed after administration of $30 \mathrm{~Gy}$ of radiation.

Although the onset of radiation esophagitis is typically acute, some studies have reported complications occurring as late as 10 years after completion of radiation treatment [5]. In contrast, progressive dysphagia usually appears at least 2 months after radiotherapy [6]. The most common late complication is fibrosis leading to stricture formation, which occurs at a rate of $<2 \%$ for doses $<50$ Gy and can increase to as high as $15 \%$ for doses exceeding $60 \mathrm{~Gy}$. Strictures usually appear at least 3 months after treatment, with a median onset time of 6 months [2]. Younger age at the time of radiation therapy has been associated with a later onset of radiation esophagitis symptoms [5].

Treatment of acute radiation esophagitis addresses symptoms and includes proton-pump inhibitors and dietary modifications [5]. A chronic complication, development of strictures, is managed with endoscopic dilation. Radiation esophagitis usually improves after radiation therapy has been stopped. However, in patients receiving combined CRT for lung cancer, recurrent esophagitis can occur after chemotherapy [14]. Furthermore, radiation-induced carcinoma can develop in areas of chronic inflammation [4]. In the present case, endoscopic findings revealed improvement at 3 weeks after the end of radiation therapy.

In conclusion, we have reported a case of acute radiation esophagitis developing in a patient with oral carcinoma with multiple bone metastases who received 30 Gy of radiation. Endoscopic findings 3 weeks after the end of radiation therapy revealed dramatic improvement of radiation esophagitis. Neutropenia appears to be one of the worsen factors of acute radiation esophagitis.

\section{Statement of Ethics}

Written informed consent was obtained from the patient for publication of this case report and any accompanying images.

\section{Conflict of Interest Statement}

The authors declare no financial disclosures or conflicts of interest. 


\section{Case Reports in Gastroenterology}

\section{Funding Sources}

There were no funding sources.

\section{Author Contributions}

All authors carried out and confirmed the diagnosis, provided the details of the case, and contributed to the design of the report. T.C. and H.Y. drafted the manuscript. All authors have read and approved the final version of the manuscript.

\section{References}

1 Ahn SJ, Kahn D, Zhou S, Yu X, Hollis D, Shafman TD, et al. Dosimetric and clinical predictors for radiationinduced esophageal injury. Int J Radiat Oncol Biol Phys. 2005 Feb;61(2):335-47.

2 Coia LR, Myerson RJ, Tepper JE. Late effects of radiation therapy on the gastrointestinal tract. Int J Radiat Oncol Biol Phys. 1995 Mar;31(5):1213-36.

3 Trowers E, Thomas C Jr, Silverstein FE. Chemical- and radiation-induced esophageal injury. Gastrointest Endosc Clin N Am. 1994 Oct;4(4):657-75.

4 Chowhan NM. Injurious effects of radiation on the esophagus. Am J Gastroenterol. 1990 Feb;85(2):115-20.

5 Mahboubi S, Silber JH. Radiation-induced esophageal strictures in children with cancer. Eur Radiol. 1997;7(1):119-22.

6 Mascarenhas F, Silvestre ME, Sá da Costa M, Grima N, Campos C, Chaves P. Acute secondary effects in the esophagus in patients undergoing radiotherapy for carcinoma of the lung. Am J Clin Oncol. 1989 Feb;12(1):34-40.

7 Trotti A, Colevas AD, Setser A, Rusch V, Jaques D, Budach V, et al. CTCAE v3.0: development of a comprehensive grading system for the adverse effects of cancer treatment. Semin Radiat Oncol. 2003 Jul;13(3):176-81.

8 Hasatani K, Tamamura H, Yamamoto K, Aoyagi H, Miyanaga T, Kaizaki Y, et al. Efficacy of endoscopic evaluation of acute radiation esophagitis during chemoradiotherapy with proton beam therapy boost for esophageal cancer. Digestion. 2020;101(4):366-74.

9 Palma DA, Senan S, Oberije C, Belderbos J, de Dios NR, Bradley JD, et al. Predicting esophagitis after chemoradiation therapy for non-small cell lung cancer: an individual patient data meta-analysis. Int J Radiat Oncol Biol Phys. 2013 Nov;87(4):690-6.

10 Dillman RO, Seagren SL, Propert KJ, Guerra J, Eaton WL, Perry MC, et al. A randomized trial of induction chemotherapy plus high-dose radiation versus radiation alone in stage III non-small-cell lung cancer. N Engl J Med. 1990 Oct;323(14):940-5.

11 Takeda K, Nemoto K, Saito H, Ogawa Y, Takai Y, Yamada S. Dosimetric correlations of acute esophagitis in lung cancer patients treated with radiotherapy. Int J Radiat Oncol Biol Phys. 2005 Jul;62(3):626-9.

12 Everitt S, Duffy M, Bressel M, McInnes B, Russell C, Sevitt T, et al. Association of oesophageal radiation dose volume metrics, neutropenia and acute radiation oesophagitis in patients receiving chemoradiotherapy for non-small cell lung cancer. Radiat Oncol. 2016 Feb;11(1):20.

13 Belderbos J, Heemsbergen W, Hoogeman M, Pengel K, Rossi M, Lebesque J. Acute esophageal toxicity in nonsmall cell lung cancer patients after high dose conformal radiotherapy. Radiother Oncol. 2005 May;75(2):157-64.

14 Greco FA, Brereton HD, Kent H, Zimbler H, Merrill J, Johnson RE. Adriamycin and enhanced radiation reaction in normal esophagus and skin. Ann Intern Med. 1976 Sep;85(3):294-8. 
Case Reports in Gastroenterology
Case Rep Gastroenterol 2020;14:453-457

DOI: $10.1159 / 000508930$

(c) 2020 The Author(s). Published by S. Karger AG, Basel www.karger.com/crg

Chiba et al:: Radiation Esophagitis with Oral Carcinoma and Bone Metastasis

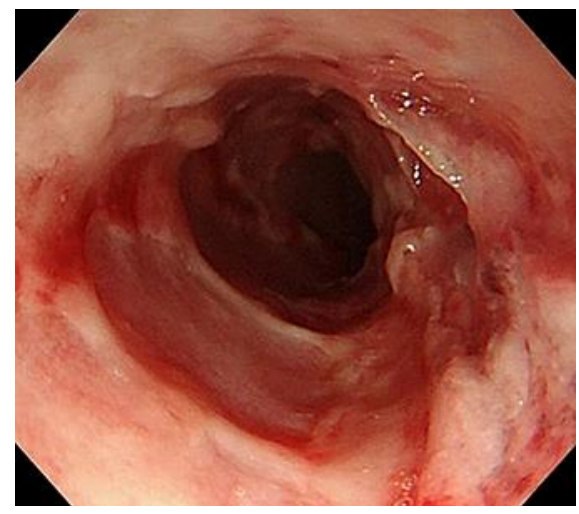

Fig. 1. Upper gastrointestinal endoscopy findings after delivery of 30 Gy of radiation therapy. Upper gastrointestinal endoscopy revealed erythema, ulceration, and spontaneous bleeding in the esophagus. Severe radiation esophagitis (endoscopic FARE grade 4) was observed.

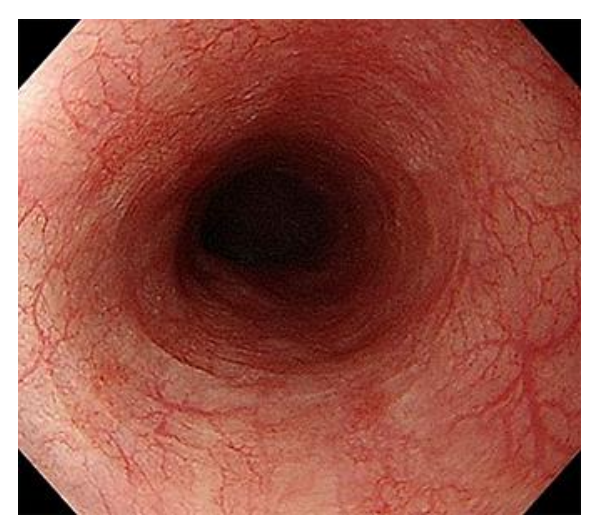

Fig. 2. Upper gastrointestinal endoscopy findings 3 weeks after the end of 30 Gy of radiation therapy. After 3 weeks, upper gastrointestinal endoscopy showed dramatic improvement of radiation esophagitis to FARE grade 1. 